\section{Localization of the corticotropin-releasing hormone receptor gene on mouse Chromosome 11}

\author{
H.L. Burrows, ${ }^{1,2}$ A.F. Seasholtz, ${ }^{3,4}$ S.A. Camper ${ }^{1}$ \\ 'Department of Human Genetics, The University of Michigan Medical \\ School, Ann Arbor, Michigan 48109-0618, USA \\ ${ }^{2}$ Graduate Program in Cellular and Molecular Biology, The University \\ of Michigan Medical School, Ann Arbor, Michigan 48109-0618, USA \\ ${ }^{3}$ Department of Biological Chemistry, The University of Michigan \\ Medical School, Ann Arbor, Michigan 48109-0618, USA \\ ${ }^{4}$ Mental Health Research Institute, The University of Michigan Medical \\ School, Ann Arbor, Michigan 48109-0618, USA
}

Received: 28 September 1994 / Accepted: 29 September 1994

Species: Mouse

Locus name: Corticotropin-releasing hormone receptor

Locus symbol: Crhr

Map position: $C r h r$ is localized on mouse Chr 11: centromereD11Mit1-(2.4 \pm 1.6$)-D 11$ Bir4-(4.7 \pm 2.3$)-D 11$ Bir7-(8.6 \pm 2.9$)-$

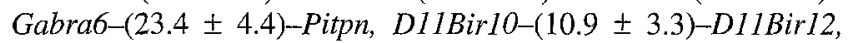

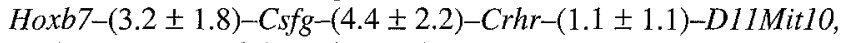
D11Bir14-(5.4 \pm 2.3)-D11Bir15-telomere.

Method of mapping: $\mathrm{Crh} r$ was localized by haplotype analysis of 90 progeny from an interspecific backcross, (C57BL/6J $\times M$. spretus) $\mathrm{F}_{1} \times \mathrm{C} 57 \mathrm{BL} / 6 \mathrm{~J}[1]$.

Molecular reagents: A 389-bp rat Crhr cDNA (rCRH-R7) containing coding sequence corresponding to amino acids 203 through 332 of the corticotropin-releasing hormone (CRH) receptor was produced by RT-PCR amplification of polyadenylated rat cortex RNA. The oligonucleotides used for the PCR amplification were: 5'ATGTT C/T TT C/T TGGATGTT C/T GG- 3' and 5' - AC G/A AA G/A AANA G/A CAT G/A TANGT-3'. These degenerate primers were designed on the basis of the human $\mathrm{CRH}$ receptor amino acid sequence [2]. The identity of the clone was confirmed by comparison of the partial DNA sequence of rCRH-R7 to the rat CRH receptor sequence $[3,4]$

Allele detection: A $B g l$ polymorphism was detected in mouse genomic DNA by hybridization of Southern blots with the rCRHR7 probe and a final stringency wash of $0.1 \times$ SSC and $0.1 \%$ SDS at $57^{\circ} \mathrm{C}$. A $M$. spretus-specific restriction fragment of $7.9 \mathrm{~kb}$ and a $6.4 \mathrm{~kb}$ C57BL/6J-specific fragment were observed.

Previously identified homologs: None

Discussion: The CRH receptor is a member of the G-protein coupled, calcitonin/VIP/GRF receptor superfamily $[2,4,5]$. In pituitary corticotropes, the binding of $\mathrm{CRH}$ to the $\mathrm{CRH}$ receptor leads to the activation of adenylate cyclase, which stimulates the synthesis and secretion of adrenocorticotropin hormone (ACTH). ACTH can then act on the adrenal cortex to increase the production of glucocorticoids [6]. In addition to its role in the hypothalamopituitary-adrenal axis, the $\mathrm{CRH}$ receptor has been found in many areas of the nervous system and in some peripheral tissues [7]. In humans, abnormal CRH levels have been associated with reciprocal changes in the levels of CRH receptors. CRH hypersecretion, which has been correlated with major depression, can lead to the downregulation of CRH receptors [8]. Also, decreases in $\mathrm{CRH}$ levels, such as in Alzheimer's disease, have been associated with

Correspondence to: S.A. Camper

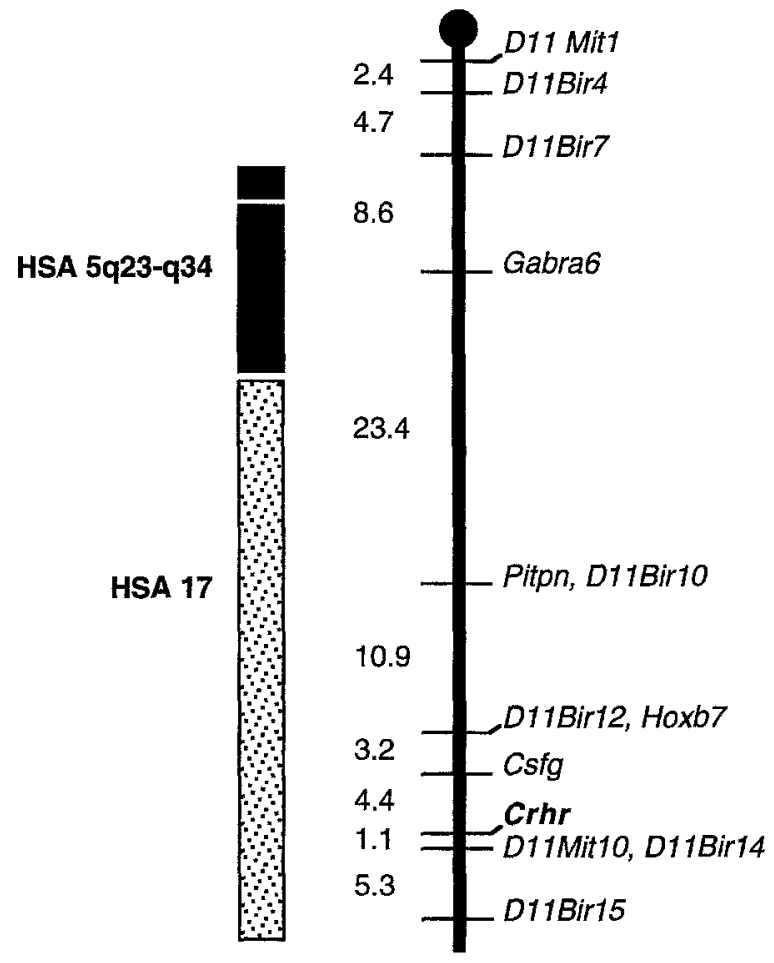

Fig. 1. The localization of Crhr on mouse Chr 11 is consistent with the assignment of CRHR to human Chr 17. Haplotype analysis and minimization of crossover events was used to generate a map of mouse Chr 11 (right) [1]. Genetic distances are in $\mathrm{cM}$ (left). The regions of extensive synteny homology between MMU 11 and human chromosomes are indicated on the left. In addition to Chrs 5 and 17, which are shown, the proximal region of mouse Chr 11 shows synteny homology to human Chrs $22,7,2$, and 16 [11].

increased levels of CRH receptor binding [9]. This suggests that regulation of CRH receptor levels may be important for homeostasis.

CRHR has been previously assigned to human Chr 17 [10]. Crhr is localized to the region of mouse Chr 11 that exhibits extensive synteny homology to human Chr 17 [11]. Thus, the mapping of Crhr is consistent with the chromosome assignment of the CRHR human gene.

Acknowledgments: We would like to thank The Jackson Laboratory for providing the backcross DNA. This work was supported by National Institutes of Health (R29 MH 49463, S.A. Camper; R29 DK 42730, A.F. Seasholtz; T32GM07863, H.L. Burrows).

\section{References:}

1. Rowe, L.B., Nadeau, J.H., Turner, R., Frankel, W.N., Letts, V.A., Eppig, J.T., Ko, M.S.H., Thurston, S.J., Birkenmeier, E.H. (1994). Mamm. Genome 5, 253-274.

2. Chang, C., Pearse II, R.V., O'Connell, S., Rosenfeld, M.G. (1993). Neuron 11, 1187-1195.

3. Perrin, M.H., Donaldson, C.J., Chen, R., Lewis, K.A., Vale, W.W. (1993). Endocrinology 133, 3058-3061.

4. Chen, R., Lewis, K.A., Perrin, M.H., Vale, W.W. (1993). Proc. Natl. Acad. Sci. USA 90, 8967-8971.

5. Vita, N., Laurent, P., Lefort, P., Lelias, J., Kaghad, M., Le Fur, G., Caput, D., Ferrara, P. (1993). FEBS Lett. 335, 1-5. 
6. Vale, W., Spiess, J., Rivier, C., Rivier, J. (1981). Science 213, 1394 1397.

7. Owens, M.J., Nemeroff, C.B. (1991). Pharmacol. Rev. 43, 425-473,

8. Nemeroff, C.B., Owens, M.J., Bissette, G., Andorn, A.C., Stanley, M. (1988). Arch. Gen. Psychiatry 45, 577-579.

9. De Souza, E.B., Whitehouse, P.J., Kuhar, M.J., Price, D.L., Vale, W.W. (1986). Nature 319, 593-595.

10. Chen, R., Lewis, K.A., Perrin, M.H., Vale, W.W. (1994). Proceedings of the 76th Annual Meeting of the Endocrine Society, Anaheim, p. 217.

11. Nadeau, J.H., Davisson, M.T., Doolittle, D.P., Grant, P., Hillyard, A.L., Kosowsky, M.R., Roderick, T.H. (1992). Mamm. Genome 3, $480-536$.

\section{Assignment of the BM203 DNA segment to U16 bovine synteny group by PCR}

\author{
A. Heriz, M.V. Arruga, L.V. Monteagudo, \\ M.T. Tejedor
}

Laboratorio de Citogenética y Genética Molecular, Facultad de Veterinaria, Miguel Servet, 177, 50013 Zaragoza, Spain

Received: 20 September 1994 / Accepted 21 September 1994

Species: Cattle

Locus name: DNA segment BM203

Locus symbol: BM203

Map position: Syntenyc group number $\mathrm{U} 16$

Method of mapping: Somatic cell hybrids and PCR

Molecular reagents: PCR primers: (+) 5'-GGGTGTGACATTTTGTTCCC- $3^{\prime}$ and (-) $5^{\prime}$-CTGCTCGCCACTAGTCCTTC-3' ${ }^{\prime}$ [1]. The specific annealing temperature used was $58^{\circ} \mathrm{C}$.

Discussion: The BM203 DNA segment is a microsatellite with 11 alleles [1]. A somatic cell panel consisting of 29 interspecific Chinese hamster $\times$ cattle hybrid clones $[2,3]$ has been studied for the BM203 locus, with bovine blood samples and hamster Wg3he12 cells [4] as controls. PCR methodology is accepted as an efficient method to gene mapping [5]. Two PCR products between 203 and $233 \mathrm{bp}$ from the insite bovine DNA and a PCR product between 203 and 233 bp from some of the hybrid DNA samples have been obtained. These results are shown in Fig. 1.

The $\varphi$ values [6] were calculated for synteny between the BM203 locus and 25 loci belonging to 22 syntenic groups. The highest $\varphi$ value of 0.73 was obtained with the AK 1 gene, which is the marker used for the U16 bovine syntenic group (Chromosome 11). It can be concluded that this locus is in the U16 synteny group,

\section{Correspondence to: M.V. Arruga}

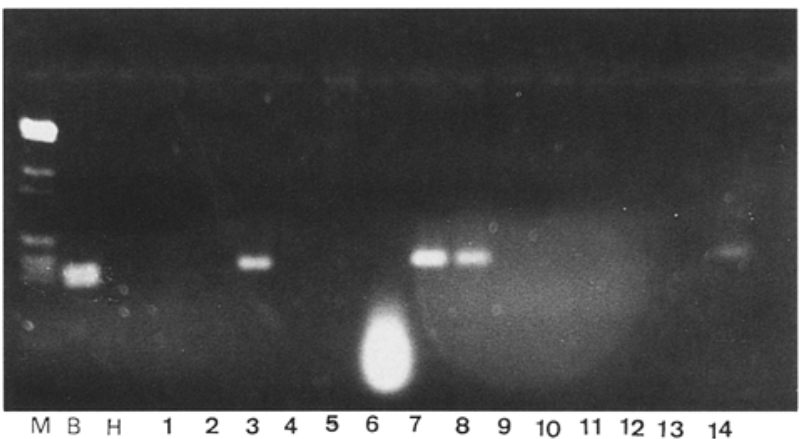

Fig. 1. Analysis of the BM203 PCR products. Lanes M, B, and H correspond to DNA marker, bovine and hamster controls. Lanes 1 to 14 show hybrid clones. Two fragments between 203 and $233 \mathrm{bp}$ in the bovine control and a band between 203 and 233 in the positive clones numbered $3,7,8$ and 14 can be seen. with a probability of $P=0.96$ and an error level of $Q=0.04$. The assignment of these polymorphic loci to the bovine genome map contributes to cover the genome with a highly polymorphic marker. So we have contributed to extend the source of highly polymorphic markers necessary for constructing a useful genetic marker map in cattle.

Acknowledgments: This work is part of the European Bovmap Project and is supported by a grant from the European Union (DG XII, Biotechnology) and CICYT Project number GAN91-1327.

\section{References:}

1. Bishop, M.D., Kappes, S.M., Keele, J.W., Stone, R.S., Sunden, S.L.F., Hawkins, G.A., Solinas Toldo, S., Fries, R., Grosz, M.D., Yoo, J., Beattic, C.W. (1994). Genetics 136, 619-639.

2. Monteagudo, L.V., Tejedor, M.T., Arniga, M.V., Mazhar, K., Pinder, S.J., Savva, D., Skidmore, C.J. (1991). Res. Vet. Sci. 52, 264-265.

3. Arruga, M.V., Monteagudo, L.V., Tejedor, M.T. (1992). Cytogenet. Cell Genet. 59, 45-47.

4. Echard, G., Gellin, J., Benne, F., Gillois, M. (1984). 5th Eur. Colloq. Cytogenet. Domest. Anim. 237-252.

5. Heriz, A., Arruga, M.V., Monteagudo, L.V., Tejedor M.T., Pitel, F., Echard, G. (1995). Mamm. Genome, in press.

6. Chevalet, C., Corpet, F. (1986). Cytogenet. Cell Genet. 43, 132-139.

\section{Localization of the neuronal form of nitric oxide synthase to mouse Chromosome 5}

\section{C.G.L. Lee, A.R. Gregg, W.E. O'Brien}

Department of Molecular and Human Genetics, Baylor College of Medicine, One Baylor Plaza, Houston, Texas 77030

Received: 16 September 1994 / Accepted: 22 September 1994

Species: Mouse

Locus name: Nitric oxide synthase (neuronal form)

Locus symbol: Nos1

Map position: centromere-D5Mit9-(5.38 \pm 2.34$)-D 5 B i r 18-(1.07$

$\pm 1.07)-D 5 B i r 19-(3.23 \pm 1.83)-N o s 1-(15.05 \pm 3.71)-Z p 3-(2.15 \pm$ 1.50)-Pmv 12

Method of mapping; Determined from 93 interspecific backcross progeny derived from matings of $(\mathrm{C} 57 \mathrm{BL} / 6 \mathrm{~J} \times$ Mus spretus $) \mathrm{F}_{1} \times$ C57BL/6J mice as described [1].

Database deposit information: MGD accession number MGDCREX-181

Molecular reagents: 578-bp fragment obtained by RT-PCR of mouse brain cDNA. This corresponds to bps 401-979 of the rat cDNA sequence (Accession number: $\times 59949$ ) [2].

Allele detection: RFLP analysis of a PstI polymorphism. M. spretus-specific band is $2.4 \mathrm{~kb}$, while the $\mathrm{C} 57 \mathrm{BL} / 6 \mathrm{~J}$-specific band is $2.8 \mathrm{~kb}$.

Previously identified homologs: The human form of the neuronal nitric oxide synthase was localized by use of a panel of somatic cell hybrids to human Chromosome (Chr) 12q14-qter [3] and by fluorescent in situ hybridization to $12 q 24.2-24.31$ [4].

Discussion: Nitric oxide synthase (NOS) catalyzes the formation of nitric oxide and citrulline from arginine. Several forms of NOS have been identified, including the inducible macrophage NOS, the constitutive endothelial NOS, as well as the neuronal NOS. Nitric oxide, the product of NOS, has been shown to be an important biological mediator [5]. The neuronal form of NOS has been implicated to play a role in long-term potentiation, serving as a retrograde neurotransmitter. Disruption of the neuronal NOS gene by homologous recombination did not affect viability or fertility although the mice developed a phenotype resembling the human infantile pyloric stenosis [6]. By interspecific backcross

Correspondence to: W.E. O'Brien 